\title{
Modern Approaches to Risk Management and Their Use in Customs
}

\author{
Vita Afanasieva ${ }^{1}$, Leonid Ivanov ${ }^{1}$, Dmytro Yanushkevych ${ }^{1}$ \\ ${ }^{1}$ Kharkiv Institute of Trade and Economics of Kyiv National University of Trade and Economics \\ 8 Otakara Yarosha prov., Kharkiv, 61045, Ukraine
}

DOI: $10.22178 /$ pos.21-6

LCC Subject Category: HD61

Received 03.04.2017

Accepted 19.04.2017

Published online 21.04.2017

Corresponding Author: Dmytro Yanushkevych, yada_nmc@ukr.net

(C) 2017 The Authors. This article is licensed under a Creative Commons Attribution 4.0 License (c) (1)

\begin{abstract}
In the article the analysis of experience and best practices of Europe and the world regarding the methods and tools of risk management in customs affairs. In accordance with the requirements of the Kyoto Convention the risk management is the main basic principle of modern customs control methods, which allows optimal use of resources of customs bodies, without reducing the effectiveness of customs controls, and exempt the majority of foreign trade operators from unnecessary bureaucratic control. Procedures based on risk management, concentrate customs control on areas, where there is the greatest risk, allowing the bulk of goods and individuals relatively free to pass the checkpoint at the customs border Special attention is paid to the principles and methods of risk management and their impact on the simplification of customs procedures through the use of risk-based thinking. The paper discusses the problems concerning the application and implementation of modern risk management techniques in customs procedures subject to the requirements of international standards ISO for the quality management system and risk management based on risk-based thinking.
\end{abstract}

Keywords: customs code; risk management; risk-based thinking; customs risks; customs control; international standards; frameworks; process approach; system of quality management.

\section{Introduction}

Dynamics of the development of modern economic space requires participants to economic relations, a timely response to the risks that they face in their work. It is primarily concerned with the state of customs, which is part of the public administration system.

The implementation of the tasks entrusted to the state customs involves achieving a balance between regulatory control and facilitation of international trade. At the same time, there are customs risks and risks in the management of the customs bodies which together comprise a system, which is a significant obstacle to carry out the functions of state management of customs business. A clear view of all the many risks and the relationship between them is essential to minimize their negative effects and improve the effectiveness of the implementation of the state customs. Risks arising in customs is an integral part of overall system risk.
The Association agreement between Ukraine and the European Union (EU), requires a restructuring of customs authorities of Ukraine in the direction of simplification and harmonization of customs procedures in accordance with the requirements of the ISO international standards, World Customs Organization Framework of Standards to secure and facilitate global trade (WCO SAFE Framework of Standards) and the EU Customs Code. One of the prerequisites of this transformation is to optimize customs control through the application of the risk management (RM). This will boost foreign trade and impact on the simplification of customs procedures, fighting smuggling and violations of customs regulations.

Currently, substantial improvement needs a number of issues with regard to the implementation of international experience in the practice of the implementation of customs, introduction of risk-oriented instruments of customs control, the formation of an effective RM with the use of 
modern risk management techniques, which is due to:

- the necessity of systematization of the world experience of risk management in customs and the urgent need for harmonization of the domestic regulatory framework in the field of customs in accordance with modern requirements;

- introduction in practice of work of customs authorities of modern risk management systems based on the use of risk-based thinking in accordance with the requirements of international standards ISO 9001, ISO 31000 and ISO 31010;

- the formation of the latest trends contributing to the revision of approaches to ensuring efficiency of customs control at the expense of concentration of material, human resources customs in areas where there is the greatest likelihood of customs risk;

- mainstreaming of issues of formation of effective system and mechanism of risk management in the context of the implementation of customs control;

- the need for the development and implementation of effective scientific-methodical and normative-legal support of increasing the efficiency of RM.

Currently, well-researched questions of the risk management system in customs and ensuring the customs security. Analysis of research in the field of the theory and practice of customs risk has shown that issues of organization, regulation and functioning of the risk management system, its further improvement in customs bodies in the conditions of formation of market economy in its theoretical and practical work dealt with such representatives of science and practice: I. Berezhnyuk [1], H. Berg [2], O. Coundoul \& A. M. Geourjon, [3], O. Dzhumurat [4], Yu. Gupanova [5], B. Laporte [6], P. Pashko [7], M. Velychko [8], D. Widdowson [9], N. Arkhireiska [21]. However, the development and introduction in practice of activity of customs bodies the use of modern management methods on the basis of risk-based thinking is rapid and dynamic in nature. This necessitates a systematic study of the main global trends and their practical application in the customs authorities.

The aim of this research. Learning from the experience and best practices of Europe and the world on issues of risk management, which is based on the risk - based thinking, the develop- ment and use of modern statistical methods for risk management in practical activity of customs authorities subject to the requirements of the ISO international standards, WCO SAFE Framework of Standards and the EU Customs Code.

\section{Materials and Methods}

Materials - customs legislation of the WCO and EU, ISO international standards, scientific knowledge, scientific methods of research - systemic and structural-functional analysis, classification and synthesis.

\section{Results}

Customs control and customs clearance of goods and means of transport can be attributed to the customs service, because the service is the result of at least one activity, necessarily performed in collaboration of the supplier (the customs authority) and the customer (the person moving goods and vehicles), and usually intangible. The provision of the service may include [10]:

- actions performed with material goods presented by the customer (customs control, identification of goods for customs examination);

- actions performed with intangible products presented by the customer (for example, declaration of customs value, needed for calculation of customs payments);

- providing intangible products (e.g., submission of information necessary for implementation of customs control and customs clearance of goods and vehicles in the context of knowledge transmission);

- creation of favorable conditions for the customer (for example, acceleration of customs clearance of goods moved across the customs border of Ukraine).

The fundamental concepts, principles of management quality in customs describes the international standard ISO 9000:2015 [11]. A significant place to improve the quality regarding the implementation of customs procedures owned by the risk management system $[12,13]$.

Customs procedures should be based upon the use of modern methods and effective controls to combat fraud, protect consumer health and safety and promote legitimate trade, have led customs authorities to seek a more structured 
and systematic method of risk management. Customs is required to address risk wherever it is found and increasingly as early in the supply chain as possible. Together with other key buildings blocks outlined in the WCO's Customs in the 21st Century strategic vision, and standards and guidelines contained in the revised Kyoto Convention and the SAFE Framework of Standards, the application of risk management is a critical element that underpins all modern customs authorities $[14,15,23]$.

In accordance with the requirements of the Kyoto Convention the risk management is the main basic principle of modern customs control methods, which allows optimal use of resources of customs bodies, without reducing the effectiveness of customs controls, and exempt the majority of foreign trade operators from unnecessary bureaucratic control. Procedures based on risk management, concentrate customs control on areas, where there is the greatest risk, allowing the bulk of goods and individuals relatively free to pass the checkpoint at the customs border [16].

On 9 October 2013, the European Parliament and the Council EC adopted Regulation (EC) No 952/2013, establishing the Union Customs Code. New EU law, the Union Customs Code introduced on 1 May 2016. There will be a number of changes to how goods cross EU borders and some transitional arrangements will operate until 2020. In the Customs Code of the EU, great attention is paid to the implementation of risk management in customs.

In accordance with the Customs Code of the EU [17], risk means "the likelihood and the impact of an event occurring, with regard to the entry, exit, transit, movement or end-use of goods moved between the customs territory of the Union and countries or territories outside that territory and to the presence within the customs territory of the Union of non-Union goods, which would:

- prevent the correct application of Union or national measures;

- compromise the financial interests of the Union and its Member States; or

- pose a threat to the security and safety of the Union and its residents, to human, animal or plant health, to the environment or to consumers".
Risk management means «the systematic identification of risk, including through random checks, and the implementation of all measures necessary for limiting exposure to risk EU» [17]. As for the concept of the customs risk, applied in different countries, the approaches to its interpretation are relatively drab, but have their national peculiarities $[14,15]$.

According to the Customs code of Ukraine, "risk is understood as the probability of noncompliance with the requirements of the legislation of Ukraine on state customs affairs" [10]. In accordance with the resolution of the Cabinet of Ministers of Ukraine from 25.05.2016 No 364, approved by the order of information exchange between customs authorities and other state authorities and enterprises on the principle of «Single window» with the use of electronic means of information transfer [18].

"Single window" is defined as a facility that allows parties involved in trade and transport to lodge standardized information and documents with a single entry point to fulfil all import, export, and transit-related regulatory requirements. This order provides for the functioning of the system of risk analysis as the basis for selective monitoring of objects of customs regulation. That is, risk is equated with the probability of occurrence of events related to customs formalities, and the possible effects of the customs risks.

In scientific works $[1,5]$ were the analysis, systematization and classification of factors and sources of risk in customs activities. Classification of customs risks for source of origin are given in Table 1.

The ability to predict the probability of occurrence and minimize the risks is determined by their classification, which performs the functions of the algorithm on the basis of which developed and created the risk management system, identifies the tools and measures to minimize the negative impact on the control object under uncertainty and multi-variant approach of development. Under the classification of risk should understand the risk allocation to specific groups according to certain signs for achievement of objectives. Scientifically based risk classification allows to clearly determine the place of each species in the overall system. It creates opportunities for the effective application of relevant methods and outputs of risk management. Thus, each risk has its own system of management techniques. 
Table 1 -Classification of customs risks for source of origin

\begin{tabular}{|c|c|}
\hline The main risk factors & Sources of risk \\
\hline \multicolumn{2}{|r|}{ External factors } \\
\hline $\begin{array}{l}\text { Subjects of foreign economic } \\
\text { activity }\end{array}$ & $\begin{array}{l}\text { - completeness of payment of customs duties; } \\
\text { - the accuracy of the information in the Declaration; } \\
\text { - the existence in the market; } \\
\text { - the compliance of the equipment carriers existing requirements; } \\
\text { - the route with the transport documents }\end{array}$ \\
\hline $\begin{array}{l}\text { Characteristics of the goods } \\
\text { (cargo) }\end{array}$ & $\begin{array}{l}\text { - price indicators of the goods; } \\
\text { - quantity and weight; } \\
\text { - classification of goods under the Ukrainian classification of goods } \\
\text { of foreign economic activity (UCC FEA); } \\
\text { - the country of origin of goods; } \\
\text { - the customs regime of placement of goods; } \\
\text { - quality of goods; } \\
\text { - intellectual property; } \\
\text { - commodities risk and commodities "group cover"; } \\
\text { - the irregularity of the flow of goods }\end{array}$ \\
\hline Customs legislation & $\begin{array}{l}\text { - the controversial provisions of separate legislative acts; } \\
\text { - the lack of a clear system of control and accountability for certain } \\
\text { violations of the law; } \\
\text { - the instability of the customs legislation; } \\
\text { - lack of coordination of the national customs legislation the customs } \\
\text { legislation of other countries and international conventions. }\end{array}$ \\
\hline \multicolumn{2}{|r|}{ Internal factors } \\
\hline Employees of the customs & $\begin{array}{l}\text { - the level of qualification; } \\
\text { - the negligence; } \\
\text { - professional errors; } \\
\text { - illegal actions and corruption }\end{array}$ \\
\hline Information-technical support & $\begin{array}{l}\text { - the level of provision of customs diagnostics; } \\
\text { - reliability of functioning of technical system; } \\
\text { - errors software. }\end{array}$ \\
\hline Technologies of customs control & $\begin{array}{l}\text { - the order of execution of customs formalities; } \\
\text { - risk management system; } \\
\text { - customs post-audit. }\end{array}$ \\
\hline $\begin{array}{l}\text { Interaction of customs authorities } \\
\text { with law enforcement and } \\
\text { regulatory agencies }\end{array}$ & - the importation of prohibited, defective and harmful products. \\
\hline
\end{tabular}

Analysis of the classification of risks allows customs to identify areas of risk (Table 2).

Given the above approaches to risk prevailing in the scientific community, it is believed that the use of the customs authorities the customs concept of risk may be supplemented with this component of risk as the magnitude of losses. This is due, primarily, to the fact that when analyzing the situation and making decisions to classify it to the category of risk, officials of the customs authorities shall take into account not only the probability of its occurrence, but also a potential economic or other harm, which is the place to be when it occurs. In this regard, "customs risk" needs to understand combination of the likeli- hood of violation of customs legislation and its negative consequences.

Customs authorities around the world are responsible for implementing a broad range of government policies in areas as diverse as revenue collection, trade and traveller compliance, protection of society, cultural heritage, intellectual property, collection of statistics and environmental protection. Some of these responsibilities are often carried out on behalf of other government ministries and agencies, through the implementation of a diverse range of agreed control regimes, with customs having responsibility for the administration and enforcement of relevant regulatory requirements at the point of importation and exportation. 
Table 2 - Classification of risk areas

\begin{tabular}{|c|c|}
\hline Groups & Name areas of risk \\
\hline $\begin{array}{l}\text { Customs } \\
\text { regime }\end{array}$ & $\begin{array}{l}\text { Import, reimport, export, reexport, transit, temporary import (export), customs } \\
\text { warehouse, special customs zone, duty free shop, processing on the customs } \\
\text { territory of Ukraine, processing outside the customs territory of Ukraine, } \\
\text { destruction, refusal in favor of the state }\end{array}$ \\
\hline $\begin{array}{l}\text { The possible } \\
\text { nature of the } \\
\text { violation }\end{array}$ & $\begin{array}{l}\text { - incorrect classification of goods; } \\
\text { - false information about the origin of the goods; } \\
\text { - understatement or overstatement of the customs value of the goods; } \\
\text { - failure to declare goods; } \\
\text { - smuggling and concealment from customs control; } \\
\text { - incorrect information about the grounds for the granting of benefits on } \\
\text { payment of customs payments; } \\
\text { - incorrect information about the characteristics and properties of the product; } \\
\text { - declaration of goods is not its name }\end{array}$ \\
\hline $\begin{array}{l}\text { Possible goal } \\
\text { violations }\end{array}$ & $\begin{array}{l}\text { - evasion/decrease the size of import duties; } \\
\text { - evasion/decrease the size of the export customs duties; } \\
\text { - evasion/decrease the size of special duties (anti-dumping); } \\
\text { - reimbursement of value added tax; } \\
\text { - evasion/decrease the size of the excise tax; } \\
\text { - the use of customs privileges; } \\
\text { - avoidance of non-tariff restrictions }\end{array}$ \\
\hline $\begin{array}{l}\text { Type of } \\
\text { product, in } \\
\text { respect of } \\
\text { whom could be } \\
\text { committed the } \\
\text { violation }\end{array}$ & $\begin{array}{l}\text { - agricultural products; } \\
\text { - metals and scrap; } \\
\text { - goods that contain objects of intellectual property rights; } \\
\text { - poisonous, radioactive, explosives, hazardous waste; } \\
\text { - narcotic drugs, psychotropic substances; } \\
\text { - weapons and ammunition; } \\
\text { - historical and cultural values; } \\
\text { - international trade in wild species of animals and plants under threat of } \\
\text { extinction }\end{array}$ \\
\hline
\end{tabular}

In addition to their overarching responsibility to maintain control over the cross-border movement of goods, people and conveyances, customs administrations also have a mandate to provide an appropriate level of facilitation to trade and travel, and consequently need to maintain regulatory control in a way that reduces the impact of interventionist strategies as much as possible [14].

This implies keeping the amount of intervention to the minimum necessary to achieve a policy outcome and also ensuring that regulatory requirements (red tape) are not unduly onerous or overly prescriptive.

Sometimes the pursuit of achieving a balance between intervention and facilitation has been seen as a "zero-sum" game where an increase in one would necessarily imply a decrease in the other. This is untrue and it is important to understand that control and facilitation are not mutually exclusive goals. On the contrary they are mutually reinforcing objectives and it is possible to achieve optimal levels of both.

Currently one of the most widespread and effective system of management is the quality management system, the basic requirements of which are set out in the international standard ISO 9001:2015. Introduction in activity of customs requirements and quality management principles in accordance with this standard, is a strategic decision that will enable to increase the efficiency, effectiveness, reliability and quality of customs services.

The potential benefits for customs from the implementation of the quality management system based on this standard are as follows:

- the ability to consistently provide custom services that meet customers and applicable statutory and regulatory requirements;

- empowerment to enhance customer satisfaction; 
- consideration of risks and opportunities associated with its context and objectives;

- the ability to demonstrate compliance with the requirements of the quality management system.

This international standard ISO 9001:2015 involves the use of the process approach, which is based on a dynamic cycle of Deming - Shewhart, which includes the plan-do-check-act (PDCA). In addition, the requirements of the standard are based on risk analysis and the application of the principle of quality management: customer focus, leadership, engagement of people, process approach, improvement, evidence-based decision making and relationship management [11].

The use requirements of this standard allows the customs authorities to define the processes necessary to achieve these objectives deviation from planned results, implement preventive measures to minimize the negative impacts and to maximize the opportunities as they arise.

As world practice shows, increasing the efficiency of risk management is possible due to implementation of requirements of international standards ISO 31000:2009 and ISO 31010:2009 $[12,13,22]$. International standard ISO 31000:2009 provides principles and concepts of risk management. ISO 31010:2009 is designed as a Supplement to ISO 31000 and provides guidance on the selection and application of risk assessment techniques. ISO 31000 has been adopted as a national standard by more than 50 national standards bodies covering over $70 \%$ of the global population. It has also been adopted by a number of UN agencies and national governments as a basis for developing their own riskrelated standards and policies, especially in the areas of disaster risk reduction and the management of disaster risk [19]. The standard reflects current practice and provides answers to the following questions $[12,13]$ :

\section{What can happen, and why?}

2. What consequences can be?

3. The probability of their future occurrence?

4. What factors reduce the likelihood or reduce the consequences of the risk?

Risk assessment is not a standalone event and should be fully integrated with the other components of the risk management process. Process approach in customs procedures should be applied in the development, implementation and improvement of the effectiveness of the quality management system, enhancing customer satisfaction by meeting customer requirements. This approach enables the organization to control the interrelationships and interdependencies among the processes of the system, so that the overall performance customs can be enhanced.

The process approach involves the systematic definition and management of processes, and their interactions, so as to achieve the intended results in accordance with the quality policy and strategic direction performance customs. Management of the processes and the system as a whole can be achieved using the PDCA cycle with an overall focus on risk-based thinking aimed at taking advantage of opportunities and preventing undesirable results.

The application of the process approach in a quality management system enables:

- understanding and consistency in meeting requirements;

- the consideration of processes in terms of added value;

- the achievement of effective process performance;

- improvement of processes based on evaluation of data and information.

According to the world experience and international best practice, risk management should not be seen as a static process but as an interactive process in which information is constantly updated, analyzed and considered for carrying out preventive and corrective actions. The standard ISO 31000:2009 establishes the principles, framework and processes of risk management (RM). Risk management principles the following $[12,22]$ :

- the process should create value;

- it should be an integral part of the organizational process;

- it should factor into the overall decision making process;

- it must explicitly address uncertainty;

- it should be systematic and structured;

- it should be based on the best available information;

- it should be tailored to the project;

- it must take into account human factors;

- it should be transparent and all-inclusive;

- it should be dynamic and adaptable to change;

- it should be continuously monitored and improved upon as the project moves forward. 
Risk management procedures can be divided into the following stages:

1. Identification - perform a brainstorming session where all conceivable risks are itemized.

2. Planning - once defined, plan for contingencies as part of the overall RM plan; implement controls as needed.

3. Derive safeguards - place specific «fallbacks» into the overall project plan as contingencies for $\mathrm{RM}$ if they arise.

4. Monitor - continuously monitor the project to determine if any defined (or un-expected) risks manifest themselves.

Once risks are identified and described, it is necessary to apply specific methods and actions to manage them. These include:

\section{Avoid the risk.}

2. Reduce the risk.

3. Share the risk.

\section{Retain the risk.}

A need was also expressed by risk practitioners, especially in the G20 economies, for a high-level document that reflects the way RM in multinational organizations and national governments, as well as how risk management should be incorporated into the governance and management systems of organizations. ISO standards are updated every five years. Over time, some risk practitioners noted that the ISO 31000:2009 requires a limited review to ensure that it remained relevant to users. As a result, the ISO management decided that ISO 31000:2009 should be revised because it is necessary to amend the terms and definitions that are needed in order to help users with their own documentation [19].

The widespread use of ISO 31000:2009 has prompted a variety of questions to various experts, with national standards bodies and ISO seeking clarification on certain points of the standard. These points, combined with feedback from the national mirror committees, indicated a need to provide greater clarity in some areas. Experts in risk was also expressed the need to create large corporations and governments of high level documents that reflect how risk management in multinational organizations and national governments, as well as how risk management should be embedded in the governance and management system of organizations. In this re- gard, began the decision was made on the revision of ISO 31000. The new version of the standard, which will be released by the end of 2017, provides that it will become more understandable for all users [19].

Risk-based thinking in customs can be grouped into essential categories:

- a country's legal framework, including customs legislation (Customs Code, Customs Tariff, system of customs duties and international agreements containing customs provisions);

- customs authorities (customs administrations of the states responsible for applying the customs legislation and any other authorities empowered under national law to apply certain customs legislation);

- risk management;

- customs formalities, means all the operations which must be carried out by a person and by the customs authorities in order to comply with the customs legislation;

- customs controls.

An important place in this system is customs controls $[10,17]$. Customs controls, means specific acts performed by the customs authorities in order to ensure compliance with the customs legislation and other legislation governing the entry, exit, transit, movement, storage and end-use of goods moved between the customs territory countries or territories outside that territory, and the presence and movement within the customs territory of the national of non-national goods and goods placed under the end-use procedure.

The customs authorities may carry out any customs controls they deem necessary. Customs controls may in particular consist of examining goods, taking samples, verifying the accuracy and completeness of the information given in a declaration or notification and the existence, authenticity, accuracy and validity of documents, examining the accounts of economic operators and other records, inspecting means of transport, inspecting luggage and other goods carried by or on persons and carrying out official enquiries and other similar acts.

Customs controls, other than random checks, shall primarily be based on risk analysis using electronic data- processing techniques, with the purpose of identifying and evaluating the risks and developing the necessary counter- measures, on the basis of criteria developed at national and international level. 
Customs controls shall be performed within a common RM framework, based upon the exchange of risk information and risk analysis results between customs administrations and establishing common risk criteria and standards, control measures and priority control areas.

Customs authorities shall undertake RM to differentiate between the levels of risk associated with goods subject to customs control or supervision and to determine whether the goods will be subject to specific customs controls, and if so, where $[10,17,20]$.

The RM shall include activities such as collecting data and information, analysing and assessing risk, prescribing and taking action and regularly monitoring and reviewing that process and its outcomes, based on international, and national sources and strategies. Customs authorities shall exchange risk information and risk analysis results where:

- the risks are assessed by a customs authority as being significant and requiring customs control and the results of the control establish that the event triggering the risks has occurred;

- the control results do not establish that the event triggering the risks has occurred, but the customs authority concerned considers the threat to present a high risk.

For the establishment of the common risk criteria and standards, the control measures and the priority control areas, account shall be taken of all of the following:

- the proportionality to the risk;

- the urgency of the necessary application of the controls;

- the probable impact on trade flow and on control resources.

The common risk criteria and standards shall include all of the following:

- a description of the risks;

- the factors or indicators of risk to be used to select goods or economic operators for customs control;

- the nature of customs controls to be undertaken by the customs authorities;

- the duration of the application of the customs controls.

Priority control areas shall cover particular customs procedures, types of goods, traffic routes, modes of transport or economic operators which are subject to increased levels of risk analysis and customs controls during a certain period, without prejudice to other controls usually carried out by the customs authorities.

Risk management can be carried out at the strategic, tactical and operational levels $[1,20]$. At the strategic level of RM according to the analysis, identification and assessment of risks are defined priority areas of implementation of risk management activities and approves the risk Register. The risk register should contain, in particular:

- priority directions for the development and implementation of risk management activities;

- structural units of customs bodies, specialized customs bodies, customs, responsible for the implementation of the corresponding direction;

- indicative targets for the share selected for control of movement of goods and vehicles.

At the tactical level of RM by customs authorities according to the analysis, identification and evaluation of risks and in accordance with the risk Register developed measures for risk management. For this purpose, such tools:

- risk indicators;

- risk profiles;

- orientation;

- methodical recommendations for work of officials of customs bodies according to the analysis, identification and assessment of risks in certain areas of control during customs control and clearance;

- random sampling.

At the operational level, RM, customs authorities apply the risk management instruments in specific cases of movement of goods, vehicles across the customs border of Ukraine, in particular in the implementation of control using risk management, to determine the forms and scope of customs control.

In accordance with the requirements of the WCO SAFE Framework of Standards, customs authorities of Ukraine implemented measures to improve the efficiency and quality of the implementation of customs formalities, executed when clearance of goods and vehicles moved across the customs border of Ukraine. Improving the quality of customs service's involves the use in the customs authorities of the requirements of ISO 9001 regarding the quality management system and requirements of international standards ISO 31000:2009 and ISO 31010:2009, regarding the risk management.

In ISO/IEC 31010:2009 is introduced using a number of methods and tools of RM that can be 
applied in customs. The overall risk assessment can be applied at all stages of the life cycle and usually it is used repeatedly with different levels of detail to facilitate decision-making at each stage. The choice of general approach to risk assessment affect various factors, including the availability of resources, nature and uncertainty of available data and information, complexity of applications. Table 3 illustrates the relationship between the main categories of common methods for risk assessment in accordance with the general process of risk assessment (risk identification).

Table 3 - Methods for risk assessment

\begin{tabular}{|c|c|c|c|c|c|}
\hline \multirow{3}{*}{ Tools and techniques } & \multicolumn{5}{|c|}{ Risk recognition process } \\
\hline & \multirow{2}{*}{$\begin{array}{c}\text { Risk } \\
\text { identification }\end{array}$} & \multicolumn{3}{|c|}{ Risk analysis } & \multirow{2}{*}{$\begin{array}{c}\text { Risk } \\
\text { evaluation }\end{array}$} \\
\hline & & consequence & probability & $\begin{array}{l}\text { level of } \\
\text { risk }\end{array}$ & \\
\hline \multicolumn{6}{|l|}{ 1. Search methods } \\
\hline Check lists & SA & NA & NA & NA & NA \\
\hline Primary hazard analysis (PHA) & SA & NA & NA & NA & NA \\
\hline \multicolumn{6}{|l|}{ 2. Supporting methods } \\
\hline Structured or semi-structured interviews & SA & NA & NA & NA & NA \\
\hline Brainstorming & SA & NA & NA & NA & NA \\
\hline Method Delphi & SA & NA & NA & NA & NA \\
\hline Structure "What if?" (SWIFT) & SA & SA & SA & SA & SA \\
\hline Human reliability analysis (HRA) & SA & SA & SA & SA & $\mathrm{A}$ \\
\hline \multicolumn{6}{|l|}{ 3. Methods of analysis scenario } \\
\hline Root cause analysis (RCA) & NA & SA & SA & SA & SA \\
\hline Scenario analysis & SA & SA & $\mathrm{A}$ & $\mathrm{A}$ & $\mathrm{A}$ \\
\hline Environmental risk assessment & SA & SA & SA & SA & SA \\
\hline Business impact analysis & A & SA & $\mathrm{A}$ & $\mathrm{A}$ & $\mathrm{A}$ \\
\hline Fault tree analysis & A & NA & SA & A & $\mathrm{A}$ \\
\hline Event tree analysis & $\mathrm{A}$ & SA & $\mathrm{A}$ & $\mathrm{A}$ & NA \\
\hline Cause-and-consequence analysis & $\mathrm{A}$ & SA & SA & $\mathrm{A}$ & $\mathrm{A}$ \\
\hline Cause-and-effect analysis & SA & SA & NA & NA & NA \\
\hline \multicolumn{6}{|l|}{ 4. Methods of functional analysis } \\
\hline $\begin{array}{l}\text { Failure mode and effects analysis } \\
\text { (FMEA) }\end{array}$ & SA & SA & SA & SA & SA \\
\hline $\begin{array}{l}\text { Hazard analysis and critical control } \\
\text { (HACCP) }\end{array}$ & SA & SA & NA & NA & SA \\
\hline Hazard and operability studies (HAZOP) & SA & SA & $\mathrm{A}$ & $\mathrm{A}$ & $\mathrm{A}$ \\
\hline \multicolumn{6}{|l|}{ 5. Methods of evaluating overall controls } \\
\hline Layer protection analysis (LOPA) & $\mathrm{A}$ & SA & $\mathrm{A}$ & $\mathrm{A}$ & NA \\
\hline Bow tie analysis & NA & $\mathrm{A}$ & SA & SA & $\mathrm{A}$ \\
\hline \multicolumn{6}{|l|}{ 6. Statistical methods } \\
\hline Markov analysis & $\mathrm{A}$ & SA & NA & NA & NA \\
\hline Bayesian statistics and Bayes nets & NA & SA & NA & NA & NA \\
\hline \multicolumn{6}{|l|}{ 7. Other techniques } \\
\hline Decision tree & NA & SA & SA & SA & SA \\
\hline FN curves & $\mathrm{A}$ & SA & SA & $\mathrm{A}$ & SA \\
\hline Risk indices & A & SA & SA & $\mathrm{A}$ & SA \\
\hline Consequence/probability matrix & SA & SA & SA & SA & $\mathrm{A}$ \\
\hline Multi-criteria decision analysis (MCDA) & $\mathrm{A}$ & SA & $\mathrm{A}$ & SA & $\mathrm{A}$ \\
\hline Reliability centered maintenance & SA & SA & SA & SA & SA \\
\hline Cost/benefit analysis & $\mathrm{A}$ & SA & $\mathrm{A}$ & $\mathrm{A}$ & $\mathrm{A}$ \\
\hline Business impact analysis & $\mathrm{A}$ & SA & $\mathrm{A}$ & $\mathrm{A}$ & $A$ \\
\hline
\end{tabular}

Note: SA - Strongly applicable, NA - Not applicable, A - Applicable. 
A modern compliance management approach recognizes that risk mitigation strategies can and should be applied throughout the supply chain. It also recognizes that a combination of multiple measures often leads to better results and more effective use of resources.

At the operational level, a modern risk-based compliance management approach is increasingly enabled by intelligence support. Intelligence enabled risk management brings together information and knowledge learned by Customs with a systematic approach for identifying and treating risks of greatest consequence. This is a critical process, as high risks identified through the risk management process will often be greater in number than Customs resources and ability to respond. Intelligence - a product, derived from the collection and processing of relevant information, which acts as a basis for user decision-making. This is the point where intelligence holdings inform decision makers of a recommended priority order for intervention and assist decisions about where Customs resources should be mobilized and deployed.

At the planning stage of the cycle PDCA, it is advisable to use qualitative methods of the risk management system (for example - Check lists, Cause-and-effect analysis, Brainstorming etc). One of the most effective methods is Cause-andeffect analysis.

Cause-and-effect analysis - is a structured method of identifying possible causes of an undesirable event or problem. This method allows to compose the possible causal factors in the generalized category so that you can investigate various hypotheses. However, the application of this method to identify the actual cause. The reasons can only be determined on the basis of empirical data or empirically. Information represent in a diagram the "fishbone" method (also called the Ishikawa diagram) or sometimes in a tree diagram. Causal analysis provides a structured graphical representation of the list of causes of one effect. Depending on the object of research, the consequence can be positive (purpose) or negative (a problem).

The method used to study all possible scenarios and reasons proposed by the expert group. The method allows to reach a consensus opinion regarding the most likely causes, which can be further verified empirically or on the basis of available data. Most appropriate to apply this method at the beginning of the analysis, which allows to expand the range of ideas about the possible causes, and then formulate hypotheses that should be further considered in accordance with the established procedure. The construction of a causal diagram allows you to:

- to identify possible root causes and/or the main reasons for a specific investigation, problems or conditions;

- to analyze the situation and to find the relationship between the interacting factors, possibly related to the study process;

- to analyze the existing problems for taking corrective actions.

The benefits of constructing a cause-and-effect diagram are:

- support the definition of the initial reasons for the problems with the application of a structured approach;

- facilitating the work of the group of experts and making better use of expert knowledge about the product or the process;

- application easy to read a chart type to display cause-and-effect relationships;

- identification of possible causes of changes in the process;

- identification of areas of data collection for further research.

In justifying the choice of methods should consider their relevance and applicability. When combining the results of different studies, it is necessary that the methods used and obtained the original data can be compared. The choice of method is made taking into account the following factors [8]:

- research objectives;

- the needs of decision makers; the type and range of risk analyzed;

- potential magnitude of effects;

- the degree of professional competence, the need for human and other resources;

- availability of information and data; need to modify or update general risk assessment, etc.

On Figure 1 presents an example of cause-andeffect diagrams (Ishikawa diagrams).

The objectives of the overall evaluation directly marked on the choice of the methods. If carried out a comparative study of the various options, it may be appropriate to use less detailed models for the effects of the system that are not influenced by differences. 


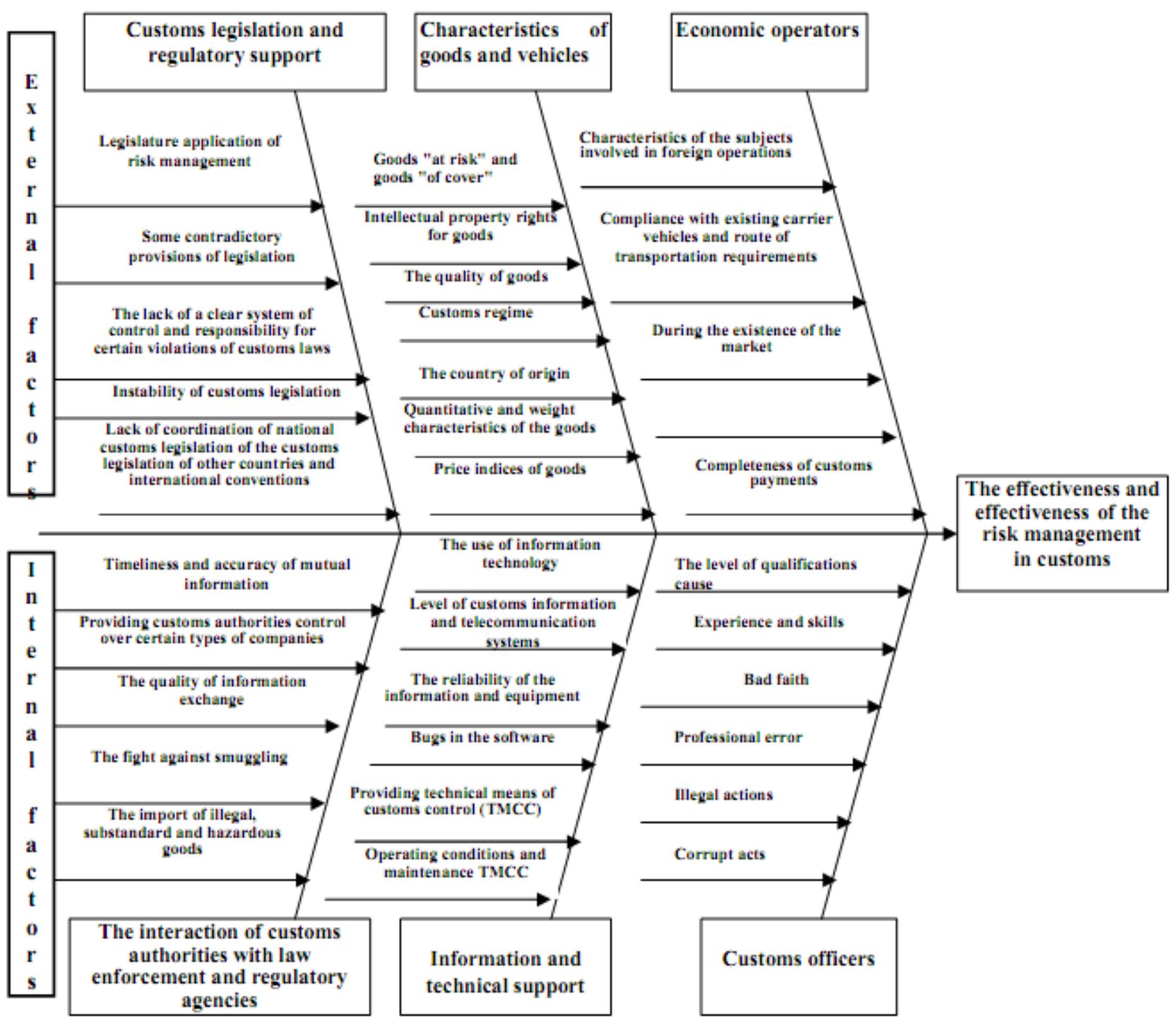

Figure 1 - Cause-and-effect diagrams (Ishikawa diagrams)

In some cases, require a high level of detail for making optimal decisions in other cases is sufficient common understanding. The decision on the overall depth risk assessment should reflect the initial effects of perception, although it may be necessary to change it after the previous assessment.

Simple, properly implemented method if it satisfies the objectives and scope of the overall evaluation can give better results than a complicated procedure but not processed. Usually it is necessary that the total cost of the evaluation were commensurate with risk potential analyzed.

The main purpose of risk-based thinking in customs is to increase the efficiency of customs control procedures and the provision of customs services.
Efficiency of customs control procedures - is the relationship between the result achieved and the resources invested, and effectiveness - the degree to which planned tasks are executed and planned results achieved.

Currently, we can distinguish several approaches to the assessment of the effectiveness of the RM system when performing tasks on state customs affairs, procedures for customs control and clearance of goods and vehicles:

- efficiency as the ratio of performance and costs;

- effectiveness as the degree of achievement of the relevant goal (the performance);

- effectiveness as the degree of compliance to best practices and current international standards (benchmarking);

- effectiveness as the degree of satisfaction with the process of its participants. 
Indicators of an estimation of efficiency of customs control procedures can be divided into three groups: on the macroeconomic indicators of the state, the efficiency of customs control pro- cedures at the micro level and the indicators assesses the level of professionalism of officials of customs authorities conducting customs control (Table 4).

Table 4 - Indicators of an estimation of efficiency of customs control procedures

\begin{tabular}{|c|c|c|}
\hline $\begin{array}{l}\text { Macroeconomic indicators of } \\
\text { the state }\end{array}$ & $\begin{array}{l}\text { The efficiency of customs control } \\
\text { procedures at the micro level }\end{array}$ & $\begin{array}{l}\text { The level of professionalism of } \\
\text { officials of customs }\end{array}$ \\
\hline $\begin{array}{l}\text { - the percentage of customs } \\
\text { duties in total revenues of the } \\
\text { state budget; } \\
\text { - the amount of accrued } \\
\text { payments to the state budget; } \\
\text { the nominal level of tariff } \\
\text { burden on the economy; } \\
\text { - implementation of the plan } \\
\text { of receipts of customs } \\
\text { payments to the budget; } \\
\text { - the level of use of electronic } \\
\text { systems and technologies } \\
\text { that reduce the time for the } \\
\text { passage of goods through } \\
\text { customs; } \\
\text { - the level of corruption; } \\
\text { - the number of reported } \\
\text { cases of smuggling and } \\
\text { violations of customs rules. }\end{array}$ & $\begin{array}{l}\text { - evaluation of procedures of customs } \\
\text { registration on one delivery (customs } \\
\text { formalities, the percentage of items } \\
\text { selected for physical inspection and } \\
\text { percentage of goods, classification code } \\
\text { of which has been changed); } \\
\text { - the average number of documents for } \\
\text { customs clearance, one delivery; } \\
\text { - the average number of documents for } \\
\text { customs clearance of one shipment; } \\
\text { - the number and duration of scheduled } \\
\text { and unscheduled checks and counter- } \\
\text { checks; } \\
\text { - the average number of days spent on } \\
\text { complex customs procedures for one } \\
\text { delivery; } \\
\text { - quantity shipments of goods to } \\
\text { customs of destination by type of } \\
\text { transport and directions of movement; } \\
\text { - the number of subjects of foreign } \\
\text { economic activity that have undergone } \\
\text { inspection after customs clearance. }\end{array}$ & $\begin{array}{l}\text { - the volume of imported } \\
\text { goods based on the one official } \\
\text { person of the customs } \\
\text { authorities; } \\
\text { - the average volume of } \\
\text { imports in quantitative terms, } \\
\text { based on the one official } \\
\text { person of the customs } \\
\text { authorities; } \\
\text { - the average number of } \\
\text { declarations by one officer } \\
\text { during the year; } \\
\text { - the volume of goods } \\
\text { furnished decorated by one } \\
\text { officer per shift(month,year); } \\
\text { - the average daily transfer of } \\
\text { customs payments the } \\
\text { customs body. }\end{array}$ \\
\hline
\end{tabular}

Using these indicators it is possible to carry out a comprehensive assessment of the effectiveness of customs control procedures and customs clearance of goods, to provide grades to the factors that influence the effectiveness of risk management in customs procedures with a view to their reduction or elimination.

\section{Conclusion}

Risk management is a core basic principle and priority direction of improvement of modern methods of customs control and customs clearance requirements the Kyoto Convention, the requirements of the WCO SAFE Framework of Standards, the roadmap for the implementation of the Framework strategy of customs cooperation between Ukraine and the EU and implementation in Ukraine from August 1, 2016, system of customs clearance «Single window». When implementing those requirements it is necessary to implement measures to improve the efficiency and quality of the implementation of customs formalities, which are performed customs clearance of goods and means of transport. In this case, the customs authorities should apply modern management methods, which are based on the principles of risk-based thinking in accordance with the requirements of international standards ISO 9001 (quality management system) and ISO 31000 and ISO 31010 (risk management). The implementation of these management practices will give the opportunity to concentrate customs control on areas where there is the greatest risk, and will allow for simplification of customs control and customs clearance of goods and means of transport.

Risk management, which is based on risk-based thinking in accordance with the requirements of international standards ISO 31000:2009 and ISO 31010:2009, allows for optimal use of resources of customs bodies, without diminishing the efficiency of customs control, and frees the majority of participants of foreign economic activity of 
unnecessary bureaucracy and will make it more practical.

The implementation proposed in the article of modern methods of management based on riskbased thinking in practical activity of customs authorities, will allow to reduce time of customs control and clearance, the costs of their conduct, minimize corruption in this area and thus will lead to increase of efficiency of activity of customs authorities.

\section{References}

1. Berezhniuk, I. H. (Ed.). (2014). Upravlinnia ryzykamy v mytnii spravi: zarubizhnyi dosvid ta vitchyzniana praktyka [Risk management in customs: foreign experience and domestic practice]. Khmelnytskyi: Vydavets A. A. Melnyk (in Ukrainian)

[Бережнюк, І. Г. (Ред.). (2014). Управління ризиками в митній справі: зарубіжний досвід та вітчизняна практика. Хмельницький: Видавець А. А. Мельник].

2. Berg, H.-P. (2010). Risk management: procedures, methods and experiences. Risk Management: Procedures, Methods And Experiences, 2(17), 79-95.

3. Geourjon, A.-M, Laporte, B., Coundoul, O., \& Gadiaga, M. (2012, April). Contrôler moins pour contrôler mieux : l'utilisation du data mining pour la gestion du risque en douane (Working Paper No P46). Retrieved from http://www.ferdi.fr/sites/www.ferdi.fr/files/publication/fichiers/P46fra_web.pdf

4. Dzhumurat, O. V. (2013). Mistse i rol ryzykiv u systemi mytnoi bezpeky derzhavy [Place and role of risk in the customs security state]. Visnyk Khmelnytskoho natsionalnoho universytetu. Seriia: Ekonomichni nauky, 2(2), 307-312 (in Ukrainian) [Джумурат, О. В. (2013). Місце і роль ризиків у системі митної безпеки держави. Вісник Хмельницького національного університету. Серія: Економічні науки, 2(2), 307-312].

5. Gupanova, Ju. E. (2012). Uchet neopredelennosti i riska pri upravlenii kachestvom tamozhennyh uslug [Uncertainty and risk accounting at customs services quality management]. Vestnik Moskovskogo gosudarstvennogo oblastnogo universiteta. Serija: Jekonomika, 2, 55-62 (in Russian) [Гупанова, Ю. Е. (2012). Учет неопределенности и риска при управлении качеством таможенных услуг. Вестник Московского государственного областного университета. Серия: Экономика, 2, 55-62].

6. Laporte, B. (2011). Risk management systems: using data mining in developing countries' customs administrations. World Customs Journal, 5(1), 17-28.

7. Pashko, P. V. (Ed.). (2012). Mytna polityka ta mytna bezpeka: kontseptualne vyznachennia ta shliakhy zabezpechennia [Customs policy and customs security: conceptual definitions and ways to ensure]. Kyiv: Znannia (in Ukrainian)

[Пашко, П. В. (Ред.). (2012). Митна політика та митна безпека: концептуальне визначення та шляхи забезпечення. Київ: Знання].

8. Velychko, O. M., Kolomiets, L. V., \& Gordiyenko, T. B. (2013). Vybir metodiv zahalnoho otsiniuvannia ryzykiv u sferi tekhnichnoho rehuliuvannia [A choice of methods of general evaluation of risks in the field of technical regulation]. Zbirnyk naukovykh prats Odeskoi derzhavnoi akademii tekhnichnoho rehuliuvannia ta yakosti, 2(3), 5-10 (in Ukrainian)

[Величко, О. М., Коломієць, Л. В., \& Гордієнко, Т. Б. (2013). Вибір методів загального оцінювання ризиків у сфері технічного регулювання. Збірник наукових праць Одеської державної академії технічного регулювання та якості, 2(3), 5-10].

9. Widdowson, D. (2004). Managing Risk in the Customs Context. In: L. De Wolf \& J. B. Sokol (Eds.), Customs Modernization Handbook (pp. 91-99). Washington: World Bank.

10. Mytnyi kodeks Ukrainy [Customs Code of Ukraine] (Ukraine) 13 March 2012, No 4495-VI. Retrieved March 10, 2017, from http://zakon3.rada.gov.ua/laws/show/4495-17 (in Ukrainian) [Митний кодекс України (Україна) 13 березня 2012, No 4495-VI. Актуально на 10.03.2017. URL: http://zakon3.rada.gov.ua/laws/show/4495-17].

11. International Organization for Standardization. (2015). Quality management systems. Requirements (ISO 9001:2015). Geneva: ISO. 
12. International Organization for Standardization. (2009). Risk management - Principles and guidelines (ISO 31000:2009). Geneva: ISO.

13. International Organization for Standardization. (2009). Risk management - Risk assessment techniques (ISO/IEC 31010:2009). Geneva: ISO.

14. World Customs Organization. (2010). Customs risk management compendium (vol. 1). Retrieved from https://goo.gl/Xlt8Xo

15. World Customs Organization. (2012, June). WCO Safe Framework of Standards. Retrieved from https://goo.gl/22IbWi

16. World Customs Organization. (2008, April 8). International Convention on the Simplification and Harmonization of Customs Procedures. Retrieved from https://goo.gl/qhvy6k

17. Laying down the Union Customs Code (EU) 9 October 2013, No 952/2013. Retrieved March 10, 2017, from http://eur-lex.europa.eu/legal-content/EN/ALL/?uri=CELEX\%3A32013R0952

18. Deiaki pytannia realizatsii pryntsypu "iedynoho vikna" pid chas zdiisnennia mytnoho, sanitarnoho, sanitarno-epidemiolohichnoho, veterynarno-sanitarnoho, fitosanitarnoho, ekolohichnoho, radiolohichnoho ta inshykh vydiv derzhavnoho kontroliu [Some questions of the principle of "single window" at customs, health, sanitary-epidemiological, veterinary, phytosanitary, environmental, radiological and other types of state control] (Ukraine) 25 May 2016, No 364. Retrieved March 10, 2017, from http://www.kmu.gov.ua/control/uk/cardnpd?docid=249107456 (in Ukrainian) [Деякі питання реалізації принципу «єдиного вікна» під час здійснення митного, санітарного, санітарно-епідеміологічного, ветеринарно-санітарного, фітосанітарного, екологічного, радіологічного та інших видів держсавного контролю (Україна) 25 травня 2016, № 364. Актуально на 10.03.2017. URL:

http://www.kmu.gov.ua/control/uk/cardnpd?docid=249107456]

19. Tranchard, S. (2015, May 13). The revision of ISO 31000 on risk management has started. Retrieved from https://www.iso.org/news/2015/05/Ref1963.html

20. Poriadok zdiisnennia analizu ta otsinky ryzykiv, rozroblennia i realizatsii zakhodiv z upravlinnia ryzykamy dlia vyznachennia form ta obsiahiv mytnoho kontroliu [Procedures for analysis and risk assessment, development and implementation of risk management measures to determine the form and scope of customs control] (Ukraine) 31 July 2015, No 684. Retrieved March 10, 2017, from http://zakon3.rada.gov.ua/laws/show/z1021-15 (in Ukrainian)

[Порядок здійснення аналізу та оцінки ризиків, розроблення і реалізації заходів з управління ризиками для визначення форм та обсягів митного контролю (Україна) 31 липня 2015, No 684. Актуально на 10.03.2017. URL: http://zakon3.rada.gov.ua/laws/show/z1021-15].

21. Arkhireiska, N. (2014). Analiz pidkhodiv do otsiniuvannia efektyvnosti mytnoi spravy [Approaches to evaluating the effectiveness of customs]. Efektyvna ekonomika, 7. Retrieved from www.economy.nayka.com.ua/?op=1\&z=3176 (in Ukrainian)

[Архірейська, Н. (2014). Аналіз підходів до оцінювання ефективності митної справи. Ефективна економіка, 7. URL: www.economy.nayka.com.ua/?op=1\&z=3176].

22. Yanushkevych, D. A. \& Ivanov, L. S. (2014). Zastosuvannia vymoh mizhnarodnykh standartiv ISO v systemi upravlinnia ryzykamy $\mathrm{v}$ mytnii spravi [The application of the requirements of ISO system of risk management in customs]. Visnyk Akademii mytnoi sluzhby Ukrainy. Seriia: Tekhnichni nauky, 2(52), 84-96 (in Ukrainian)

[Янушкевич, Д. А. \& Іванов, Л. С. (2014). Застосування вимог міжнародних стандартів ISO в системі управління ризиками в митній справі. Вісник Академії митної служби України. Серія: Технічні науки, 2(52), 84-96].

23. Ivanov, L. S., \& Yanushkevych, D. A. (2016). Tekhnichni bariery u mizhnarodnii torhivli [Technical barriers in international trade]. Zovnishnia torhivlia: ekonomika, finansy, pravo, 2(86), 15-30 (in Ukrainian) [Іванов, Л. С., \& Янушкевич, Д. А. (2016). Технічні бар'єри у міжнародній торгівлі. Зовнішня торгівля: економіка, фінанси, право, 2(86), 15-30]. 